\title{
Reduction of protein intake decreases glomerular filtration rate in young Type 1 (insulin-dependent) diabetic patients mainly in hyperfiltering patients
}

\author{
S. Rudberg ${ }^{1}$, G. Dahlquist ${ }^{2}$, A. Aperia ${ }^{1}$ and B. Persson ${ }^{1}$ \\ Departments of Paediatrics, Karolinska Institute, ${ }^{1}$ St. Göran's Children's Hospital and ${ }^{2}$ Sachs's Children's Hospital, Stockholm, Sweden
}

\begin{abstract}
Summary. The influence of different protein intake on renal function was studied in 16 Type 1 (insulin-dependent) diabetic patients, aged 15-23 years, with onset of diabetes before puberty and with a duration of diabetes between 5 and 20 years. The glomerular filtration rate, renal plasma flow, albumin excretion rate, and blood pressure were examined in a cross-over randomised order after 10 days on isocaloric diets with either $10 \%$ (i.e. $0.9 \pm 0.06 \mathrm{~g} \cdot \mathrm{kg}^{-1} \cdot \mathrm{day}^{-1}$ ) or $20 \%\left(1.9 \pm 0.1 \mathrm{~g} \cdot \mathrm{kg}^{-1} \cdot \mathrm{day}^{-1}\right)$ of the calories as protein, the latter being equal to the recommended diet. Dietary compliance was evaluated using fractional phosphate excretion and overnight urea excretion. Glomerular filtration rate was lower after the low-protein diet compared to the usual protein diet $(p<0.001)$. Patients with glomerular filtration rate above $+2 \mathrm{SD}$ of the normal mean on the usual protein diet $(n=6)$ exhibited the steepest fall in glomerular filtration rate with a mean decrease of $20 \mathrm{ml} / \mathrm{min}$ compared to $7 \mathrm{ml} / \mathrm{min}$ in those with initially normal glomerular filtration
\end{abstract}

$(p=0.01)$. Filtration fraction tended to decrease on low protein diet, more so in initially hyperfiltering patients $(p=0.09)$. Renal plasma flow remained unchanged. In patients with elevated glomerular filtration rate on usual protein diet, albumin excretion rate and systolic, but not diastolic blood pressure, were decreased on low protein diet ( $p=0.03$ and $p=0.01$, respectively) but not in initially normal-filtering patients. Mean blood glucose and serum fructosamine were unchanged on both diets. In conclusion, low protein diet decreases glomerular filtration rate independently of glycaemic control in young Type 1 diabetic patients and more so in hyperfiltering patients. This decline in glomerular filtration rate is accompanied by a decrease in albumin excretion rate and systolic blood pressure in hyperfiltering patients.

Key words: Type 1 (insulin-dependent) diabetes, renal hyperfiltration, microalbuminuria, protein restriction.
It is well known that many patients with Type 1 (insulin-dependent) diabetes already early after onset have a sustained elevated glomerular filtration rate (GFR) [1-3]. It has been proposed that glomerular hyperfiltration plays a role in the development of the increased urinary albumin excretion and the structural glomerular changes that are associated with diabetic nephropathy in humans [4]. Several prospective studies suggest that microalbuminuria is an early predictor of the glomerular lesion [5-7]. Albuminuria might also be a secondary effect of the increase in ultrafiltration pressure [8-11] that is a feature of the hyperfiltration. Supportive evidence for a causative relationship between hyperfiltration and the renal damage in diabetes has been demonstrated in studies in animals with experimental diabetes mellitus [12].

In 1954, Pullman et al. had already shown that GFR could be influenced by different protein intake in normal man [13]. More recent studies in experimentally induced diabetes in the rat [14], as well as a few clinical studies in insulin-dependent diabetic patients
$[15,16]$, have also demonstrated that hyperfiltration can be attenuated by low protein diet (LPD).

To further address the question whether an LPD affects renal function differently in hyperfiltering compared to normal-filtering diabetic patients, we have examined the effect of reduced protein intake on two groups of patients with Type 1 diabetes: one group with GFR more than +2 SD from normal mean, and a second group with normal GFR. In both groups the initial GFR used for this classification was determined when the patients were on the usual protein diet.

\section{Subjects and methods}

The study was approved by the local ethical committee and informed consent was given by patients and parents.

\section{Study population}

Seven female and 9 male patients, aged 15-23 years and with a duration of diabetes of 5-23 (mean 12) years were studied. All pa- 
Table 1. Clinical characteristics of 16 Type 1 (insulin-dependent) diabetic patients before entry into the study

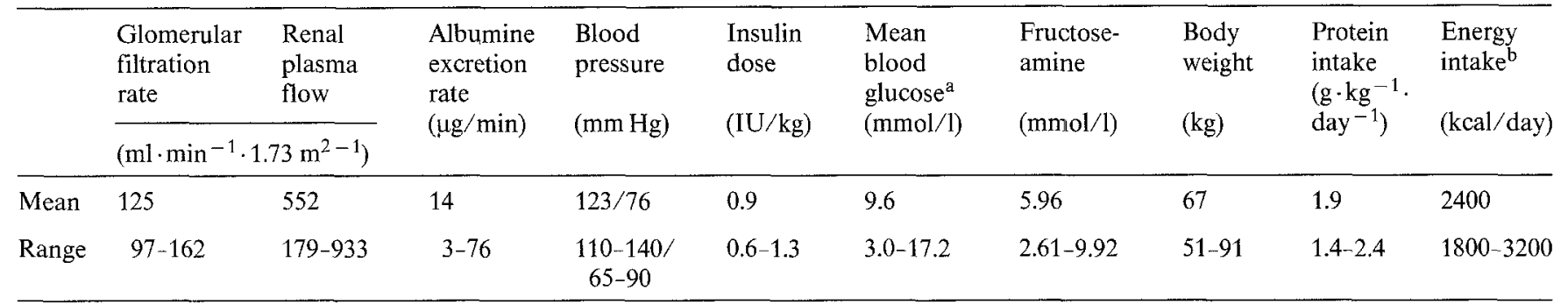

${ }^{a}$ Mean blood glucose during renal function test; ${ }^{b}$ Estimated protein and energy intake based on 5 day dietary record

tients had an onset of diabetes before puberty. Selection criteria for participation in the study were age $\geq 15$ and duration of diabetes $\geq 5$ years. Clinical characteristics are given in Table 1 .

The patients were divided into two groups according to their GFR values on the usual protein diet (UPD). 1) Group $H$ included 6 patients with byperfiltration, i.e. GFR above $127 \mathrm{ml} \cdot \mathrm{min}^{-1}$. $1.73 \mathrm{~m}^{2-1}$. This value corresponds to the mean $+2 \mathrm{SD}$ as measured by the method used in age-matched healthy control patients [17]. The mean value of GFR measured twice within the last year in these patients was $141 \pm 5 \mathrm{ml} \cdot \mathrm{min}^{-1} \cdot 1.73 \mathrm{~m}^{2-1}$ (mean \pm SEM); 2) Group $N$ included 19 patients with GFR below $127 \mathrm{ml} \cdot \mathrm{min}^{-1} \cdot 1.73 \mathrm{~m}^{2-1}$. In this group the mean value of 2 preceding GFR examinations during the last year was $124 \pm 6 \mathrm{ml} \cdot \mathrm{min}^{-1} \cdot 1.73 \mathrm{~m}^{2-1}$. The groups did not differ with respect to age, sex, or duration of diabetes (14 years in group $\mathrm{H}$ and 11 years in group $\mathrm{N}$ ). Neither did age at onset ( 5 years in group $\mathrm{H}$ and 6.5 years in group $\mathrm{N}$ ) differ between the two groups.

One male patient in group $\mathrm{N}$ (no.8) was on a continuous subcutaneous insulin infusion, the others were conventionally treated using 3-4 subcutaneous injections daily. None of the patients were taking drugs other than insulin.

All patients had Albustix negative urine tests, but 6 patients had albumin excretion rate values exceeding $15 \mu \mathrm{g} / \mathrm{min}, 2$ in group $\mathrm{H}$ and 4 in group $\mathrm{N}$ (nos. $4,6,8,9,10,11)$. The highest albumin excretion rate values were found in group $\mathrm{N}$.

Two patients in group $\mathrm{N}$ (nos. 8 and 9) had a diastolic blood pressure at the 90 th percentile for age and sex $(90 \mathrm{~mm} \mathrm{Hg}$ ), all other patients were normotensive.

All patients were examined for late complications from eyes (ophthalmoscopy) and nerves (nerve conduction velocity). Pathological findings were present only in group $\mathrm{N}$. Three patients had background retinopathy (a few microaneurysms, patients nos. 8, 9, and 11) and 4 had diminution of nerve conduction velocity compatible with incipient neuropathy (patients nos. 8, 9, 10, and 11).

Metabolic control at the time of entrance into the study measured as fructosamine in serum was equal in both groups, 5.19 (2.61-9.92) mmol/ 1 in group $\mathrm{H}$ and $6.43(3.66-9.72) \mathrm{mmol} / 1$ in group $\mathrm{N}$ (normal value $1.9-2.7 \mathrm{mmol} / \mathrm{l}$ ). No patient had been admitted to the hospital because of ketoacidosis within 6 months prior to the study.

\section{Procedure}

The day before entrance into the study, the patients were examined for GFR, renal plasma flow, albumin excretion rate, blood pressure, serum fructosamine, and mean blood glucose during the renal function test (Table 1). This examination was then repeated twice after the subjects had been on different diets as described below.

Diets. The mean energy and protein intake of the usual diet was calculated from a 5 day dietary record. The calculation was performed by a nutritionist. Estimated usual energy and protein intake is given in Table 1 . The amount of dietary protein or calories did not differ between the two groups. In group $\mathrm{H}$ mean energy intake was $2400(1800-3400) \mathrm{kcal} \cdot \mathrm{day}^{-1}$ and mean protein intake was 1.9 $(1.5-2.4) \mathrm{g} \cdot \mathrm{kg}^{-1} \cdot \mathrm{day}^{-1}$. Corresponding values for group $\mathrm{N}$ were
$2080(1800-2800) \mathrm{kcal} \cdot \mathrm{day}^{-1}$ and $1.8(1.4-2.4) \mathrm{g} \cdot \mathrm{kg}^{-1} \cdot \mathrm{day}^{-1}$, respectivly. Based on the dietary record diets containing either $10 \%$ (corresponding to $0.9 \pm 0.06 \mathrm{~g} \cdot \mathrm{kg}^{-1} \cdot$ day $^{-1}$ ) or $20 \%(1.9 \pm$ $\left.0.1 \mathrm{~g} \cdot \mathrm{kg}^{-1} \cdot \mathrm{day}^{-1}\right)$ of the calories as protein were individually designed. The sources of protein were similar in the diets, i.e. both animal and vegetarian. The protein content of the different diets did not differ between groups $\mathrm{H}$ and $\mathrm{N}$. The relative content of dietary fat was unchanged in the two diets and corresponded to $30 \%$ of the calories. The diets were based on prefabricated meals of known composition (Findus $A B$, Stockholm, Sweden) with individual recommendations of supplements of bred, butter, and milk. These isocaloric diets were taken in a randomised order during two 10-day periods with no interval between. Immediately before each renal function test, performed between 12.00 and 15.00 hours, the patients received a standard lunch at 11.30 hours with the same relative composition of protein, carbohydrates, and fat as that of the preceding 10 days.

\section{Evaluation of dietary compliance}

Overnight urea excretion (urea/creatinine ratio, enzymatic method, Boeringer Mannheim, Mannheim, FRG) was determined in urine collected at two separate occasions during the two study periods. In the same way, overnight phosphate excretion was measured in 12 patients, but fractional phosphate excretion calculated as clearance of phosphate/clearance of inulin was also determined on UPD and LPD during the renal function test in 4 portions of urine with 30 min intervals [18]. To be included in the analyses of the results, fractionatal phosphate excretion and overnight urea excretion should be higher on the UPD than on the LPD. Four patients were excluded from the study as one of these criteria was not fulfilled.

\section{Kidney function}

GFR, renal plasma flow, and filtration fraction $(\%$, calculated from GFR/RPF) were measured using the continuous infusion technique of inulin (Inulin, Laevosan, Linz, Austria) [19] and p-aminohippuric acid (PAH, Merck Sharp and Dohme, Rahway, New Jersey, USA) [20]. The patients were examined in the recumbant position. They were orally hydrated with water corresponding to $1 \%$ of the body weight during $1 \mathrm{~h}$ preceding the start of the clearance study, thereafter, with $0.25 \%$ of the body weight, every $30 \mathrm{~min}$. The clearance values were expressed per $1.73 \mathrm{~m}^{2}$ surface area.

Albumin excretion rate $(\mu \mathrm{g} / \mathrm{min})$ was measured using a radioimmunological technique (Phadebas, Uppsala, Sweden) during each clearance investigation. It was estimated from 2 portions of urine voided at 120 and $150 \mathrm{~min}$ after the initial hydration to eliminate the wash-out effect on albumin excretion rate. Fractional albumin clearance was also estimated and calculated as the clearance of albumin/clearance of inulin.

Fractional sodium excretion was measured as clearance of sodium/clearance of inulin and the urine potassium/sodium ratio was also studied using a flamometer (Kontron, Stockholm, Sweden). 
Table 2. Glomerular filtration rate, renal plasma flow, filtration fraction, serum fructosamine and mean blood glucose during clearance investigation in initially hyperfiltering, (Group $\mathrm{H}, \mathrm{GFR}>+2 \mathrm{SD}$ of normal mean) and initially normal-filtering (Group $\mathrm{N}$ ) Type 1 diabetic patients. Results after usual (UPD) and low protein (LPD) diet. Mean \pm SEM

\begin{tabular}{|c|c|c|c|c|c|c|c|c|c|c|}
\hline \multirow[b]{2}{*}{ Group } & \multicolumn{2}{|c|}{$\begin{array}{l}\text { Glomerular } \\
\text { filtration rate } \\
\left(\mathrm{ml} \cdot \min ^{-1} \cdot 1.73 \mathrm{~m}^{2-1}\right)\end{array}$} & \multicolumn{2}{|c|}{$\begin{array}{l}\text { Renal plasma flow } \\
\left(\mathrm{ml} \cdot \mathrm{min}^{-1} \cdot 1.73 \mathrm{~m}^{2-1}\right)\end{array}$} & \multicolumn{2}{|c|}{$\begin{array}{l}\text { Filtration fraction } \\
(\%)\end{array}$} & \multicolumn{2}{|c|}{$\begin{array}{l}\text { Fructosamine } \\
(\mathrm{mmol} / \mathrm{l})\end{array}$} & \multicolumn{2}{|c|}{$\begin{array}{l}\text { Mean blood glucose } \\
(\mathrm{mmol} / \mathrm{l})\end{array}$} \\
\hline & $\mathrm{H}$ & $\mathrm{N}$ & $\mathrm{H}$ & $\mathrm{N}$ & $\mathrm{H}$ & $N$ & $\mathrm{H}$ & $\mathrm{N}$ & $\mathrm{H}$ & $\mathrm{N}$ \\
\hline UPD & $144 \pm 4$ & $116 \pm 3$ & $\begin{array}{l}572 \pm 59 \\
(n=5)\end{array}$ & $569 \pm 26$ & $\begin{array}{l}26 \pm 3 \\
(n=5)\end{array}$ & $20 \pm 1$ & $4.3 \pm 0.7$ & $5.8 \pm 1.1$ & $7.7 \pm 0.7$ & $8.7 \pm 0.5$ \\
\hline LPD & $124 \pm 3$ & $109 \pm 3$ & $573 \pm 23$ & $\begin{array}{l}570 \pm 28 \\
(n=9)\end{array}$ & $23 \pm 1$ & $\begin{array}{l}19 \pm 1 \\
(n=9)\end{array}$ & $4.2 \pm 0.8$ & $5.4 \pm 0.8$ & $5.5 \pm 0.8$ & $8.7 \pm 0.7$ \\
\hline$p$ value & $<0.001$ & 0.09 & 0.84 & 0.37 & 0.09 & 0.43 & 0.89 & 0.51 & 0.46 & 0.91 \\
\hline
\end{tabular}

\section{Blood pressure measurement}

Systolic and diastolic blood pressure $(\mathrm{mm} \mathrm{Hg})$ were measured by the same observer at the start of each clearance investigation after a $15 \mathrm{~min}$ rest, left arm, sitting position, using a conventional sphygmometer technique. Diastolic blood pressure was read at phase 5.

\section{Evaluation of metabolic control}

During the study period, all subjects performed home blood glucose monitoring, and the insulin dose was adjusted according to the blood glucose values.

Blood glucose (enzymatic method, Glox, Pharmacia, Uppsala, Sweden) was also measured 10 times during a $22 \mathrm{~h}$ period in $12 \mathrm{pa}-$ tients and in all 16 patients before the intake of the standard lunch, thereafter, every half hour during the renal function test.

Serum fructosamine (Fructosamine test, Roche Diagnostica, Basel, Switzerland) [21] was determined in aliquots of blood samples obtained before each clearance investigation.

\section{Statistical analysis}

GFR, clearance of p-aminohippuric acid, and blood pressure were analysed using Student's $t$-test for paired observations and for comparisons between groups. Because of a skewed distribution of albumin excretion rate, this was analysed using the Wilcoxon's matched pairs sign test. Correlation studies were performed using either the the methods of Pearson or Speerman. A $p$ value $<0.05$ was considered statistically significant.

\section{Results}

\section{Effect of low protein diet on renal function in all diabetic patients}

Glomerular filtration rate. GFR was significantly lower after LPD, $114 \pm 3$ vs $127 \pm 4 \mathrm{ml} \cdot \mathrm{min}^{-1} \cdot 1.73 \mathrm{~m}^{2-1}$ (mean \pm SEM) after UPD $(p<0.001)$. A positive correlation between baseline GFR-values and delta GFR between UPD and LPD was seen $(r=0.67, p<0.001)$. When excluding patients with signs of late diabetic complications (patients nos $8,9,10,11$ ) this correlation was still statistically significant $(r=0.59, p=0.04)$.

Renal plasma flow and filtration fraction. Clearance of p-aminohippuric acid remained unchanged in the whole study population, $547 \pm 34$ vs $576 \pm$ $38 \mathrm{~m} \cdot \mathrm{min}^{-1} \cdot 1.73^{-1}$ (mean $\pm \mathrm{SEM}$ ) after UPD and

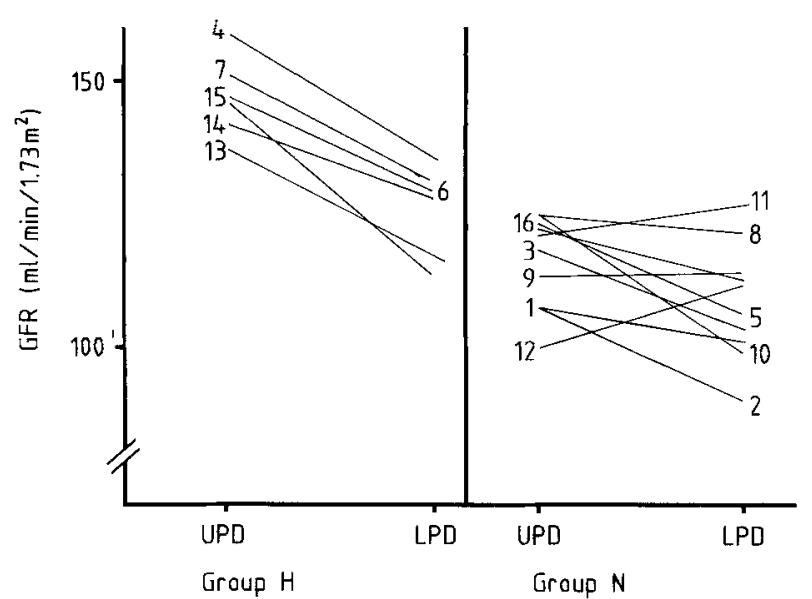

Fig. 1. GFR in young Type 1 (insulin-dependent) diabetic patients after usual (UPD) and low (LPD) protein diet. Groups $\mathrm{H}$ and $\mathrm{N}$ indicate hyperfiltering and normal-filtering groups respectively. The numbers in the figure refer to patient numbers in the text

LPD, respectively. Filtration fraction tended to be higher on UPD than on LPD, $25 \pm 3$ vs $21 \pm 1 \%$ (mean $\pm \mathrm{SEM}$ ), but the difference was not statistically significant $(p=0.17)$.

Albumin excretion rate. Median albumin excretion rate was similar at the end of both 10 day study periods: after LPD $13 \mu \mathrm{g} / \mathrm{min}$, range $4-61$, after UPD $16 \mu \mathrm{g} / \mathrm{min}$, range 6-79. Fractional clearance of albumin was also unchanged $56 \pm 11$ after LPD vs $76 \pm 12$ after UPD (mean \pm SEM, $p=0.27$ ).

Blood pressure. Systolic, but not diastolic blood pressure, was slightly decreased after LPD, $118 \pm 2$, as compared to $122 \pm 2 \mathrm{~mm} \mathrm{Hg}$ after UPD $(p=0.02)$. No correlation was seen between systolic or distolic blood pressure and GFR, but systolic blood pressure tended to be correlated to albumin excretion rate $(r=0.31$, $p=0.05$ ).

\section{Comparisons of renal function tests in hyperfiltering versus normal-filtering diabetic patients}

Glomerular filtration rate. Mean values of GFR in the two groups are given in Table 2. Individual GFR values are shown in Figure 1. The mean decrease of GFR was more pronounced in group $\mathrm{H}$ as compared 
Table 3. Albumin excretion rate and blood pressure in initially hyperfiltering (Group H, i. e. $>+2 \mathrm{SD}$ of normal mean) and normal-filtering (Group N) Type 1 diabetic patients after usual (UPD) and low protein (LPD) diet

\begin{tabular}{|c|c|c|c|c|c|c|}
\hline & \multicolumn{2}{|c|}{$\begin{array}{l}\text { Albumin excretion rate } \\
(\mu \mathrm{g} / \mathrm{min}) \text { median (range) }\end{array}$} & \multicolumn{2}{|c|}{$\begin{array}{l}\text { Blood pressure systolic } \\
(\mathrm{mm} \mathrm{Hg})\end{array}$} & \multicolumn{2}{|c|}{$\begin{array}{l}\text { Blood pressure diastolic }{ }^{a} \\
(\mathrm{~mm} \mathrm{Hg})\end{array}$} \\
\hline & $\mathrm{H}$ & $\mathrm{N}$ & $\mathrm{H}$ & $\mathrm{N}$ & $\mathrm{H}$ & $\mathrm{N}$ \\
\hline UPD & $17(9-20)$ & $16(6-79)$ & $122 \pm 4$ & $124 \pm 3$ & $74 \pm 2$ & $72 \pm 3$ \\
\hline LPD & $\begin{array}{l}10(7-14) \\
(n=5)\end{array}$ & $\begin{array}{l}16(4-61) \\
(n=8)\end{array}$ & $115 \pm 3$ & $119 \pm 3$ & $73 \pm 4$ & $74 \pm 3$ \\
\hline
\end{tabular}

a Mean \pm SEM

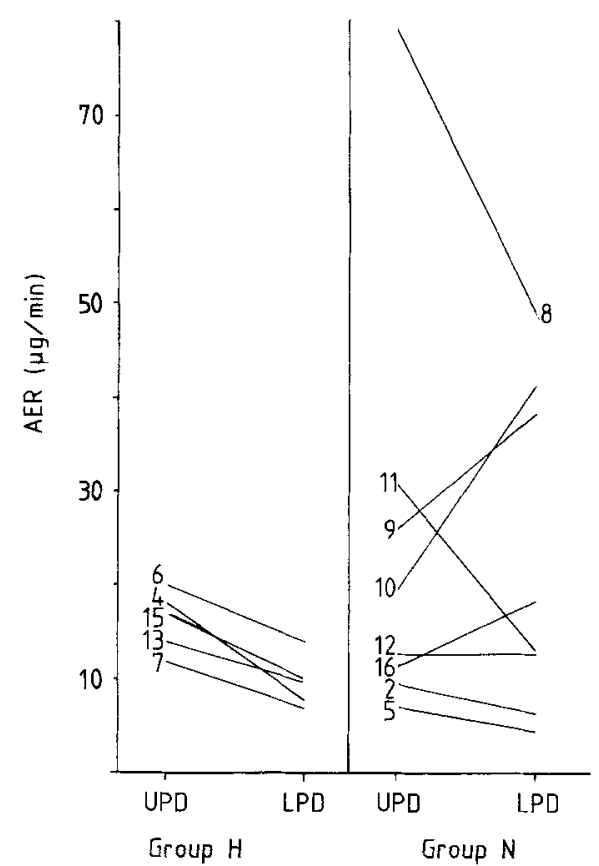

Fig. 2. AER in young Type 1 diabetic patients after usual (UPD) and low (LPD) protein diet. Groups $\mathrm{H}$ and $\mathrm{N}$ indicate hyperfiltering and normal-filtering groups respectively

to group N, $20 \pm 1.8 \mathrm{ml} / \mathrm{min}$ (mean $\pm \mathrm{SEM}$ ) and $7 \pm 3 \mathrm{ml} / \mathrm{min}$ respectively. This difference was statistically significant $(p=0.01)$.

Renal plasma flow and filtration fraction. No difference was noted in clearance of p-aminohippuric acid after LPD as compared to after UPD (Table 2) in any group. The mean value of filtration fraction tended to be higher on UPD than on LPD in the hyperfiltering group only, but this difference did not reach statistical significance $(p=0.09)$ (Table 2). Two filtration fraction and clearance of $p$-aminohippuric acid values are missing due to technical error.

Albumin excretion rate. All hyperfiltering patients reduced their albumin excretion rate on the LPD, whereas no change was found in group $\mathrm{N}$ (Table 3 ). The individual values for both groups are found in Figure 2. Values from one patient in group $\mathrm{H}$ and two patients in group $\mathrm{N}$ are missing due to sampling error. In group $\mathrm{H}$ fractional albumin clearance was reduced in all patients from $48 \pm 7 \times 10^{-8}$ on UPD to
$33 \pm 6 \times 10^{-8}$ on LPD (mean $\pm \mathrm{SEM}, p=0.03$ ). In group $\mathrm{N}$, corresponding values were $76 \pm 11 \times 10^{-8}$ on UPD and $56 \pm 11 \times 10^{-8}$ on LPD (mean $\pm S E M$, $p=1.27)$.

Blood pressure. A significant decrease in systolic, but not diastolic pressure, was found only in the hyperfiltering group after the LPD (Table 3 ).

\section{Metabolic control during low and usual protein diet}

Insulin dose was unchanged during the study period and equal in groups $\mathrm{H}$ and $\mathrm{N}, 0.9 \pm 0.005 \mathrm{IU} / \mathrm{kg}$ body weight.

Serum fructosamine remained unchanged on the two diets in both groups (Table 2). No correlation between fructosamine and GFR was seen on any diet $(r=-0.33, p=0.21$ on UPD; $r=-0.19, p=0.48$ on LPD).

Mean blood glucose during the clearance investigation was not significantly different on LPD as compared to that recorded during UPD in any group. Neither was there any difference in blood glucose values between groups $\mathrm{H}$ and $\mathrm{N}$ (Table 2). Mean blood glucose during $22 \mathrm{~h}$ was also unchanged, $9.4 \pm 0.2 \mathrm{mmol} / 1$ on UPD vs $8.5 \pm 0.4 \mathrm{mmol} / 1$ on LPD (mean \pm SEM) (Fig. 3). The mean blood glucose levels did not differ significantly in group $\mathrm{H}$ as compared to group $\mathrm{N}$.

Body weight was the same on the various diets, UPD $66.2 \pm 10.6 \mathrm{~kg}$, LPD $66.4 \pm 10.1 \mathrm{~kg}$ (mean $\pm \mathrm{SD})$.

\section{Dietary control}

Median overnight urea/creatinine excretion ratio was 28.7 (24.6-44.6) on UPD and $22.6(14.3-27.8)$ after LPD $(p=0.001)$. Fractional phosphate excretion decreased from 22 (10-32) on UPD to 17 (5-22) on LPD $(p<0.001)$. Median overnight phosphate/creatinine excretion ratio was $3.4(1.6-4.4)$ after UPD and 2.4 $(1.5-3.3)$ after LPD $(p=0.01)$. Fractional sodium excretion was $1.33 \pm 0.12$ (mean $\pm S E M$ ) on LPD vs $1.44+0.15$ on UPD $(p=0.60)$. The potassium/sodium excretion ratio was also unchanged, $0.90 \pm 0.10$ (mean \pm SEM) after LPD and $0.85 \pm 0.10$ after UPD $(p=0.43)$. 


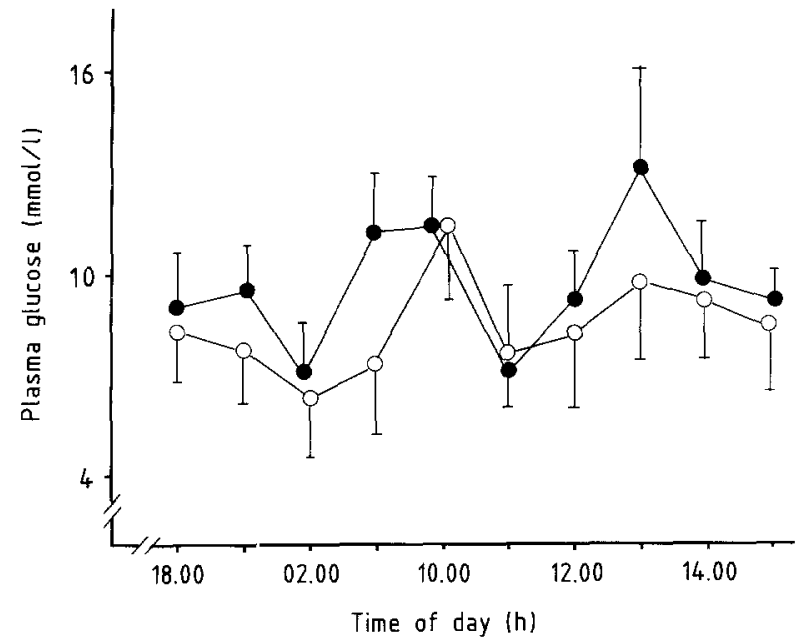

Fig. 3. Plasma glucose profiles in 12 Type 1 diabetic patients during usual $(\Theta)$ and low protein diet $(\mathrm{O})$

\section{Discussion}

This study clearly demonstrates that GFR decreases following a moderate reduction of protein intake also in patients with insulin-dependent diabetes. However, there is a considerable difference in the response of GFR to an LPD between initially hyperfiltering and normal-filtering patients. In the present study, we found that patients with supranormal elevation of GFR were more prone to reduce their GFR on an LPD than those with an initially normal glomerular filtration rate. It should be recalled, though, that this latter group was heterogenous as it included patients with and without signs of incipient nephropathy. One could therefore speculate that the different responses of GFR to LPD in hyperfiltering and normal-filtering patients might partly be due to the fact that some of the patients in group $\mathrm{N}$ had reached a stage of incipient renal damage as indicated by elevated albumin excretion rate values. Furthermore, the same patients in the normal-filtering group had, in addition, evidence of other late diabetic complications. One could therefore hypothesise that these patients might be less able to adapt their kidney function to a change in dietary protein intake; however, when excluding these patients, there was still a significant correlation between basal GFR and the magnitude of fall in GFR after LPD. This indicates a difference in the effect of LPD also between hyperfiltering and non-hyperfiltering patients without complications.

The present finding of a decline of GFR after LPD is in accordance with earlier findings in insulin-dependent diabetic patients $[15,16,22]$. However, these studies are not strictly comparable to our study, either with respect to experimental design - i.e. different amounts of protein in the diets, or regarding the clinical characteristics of the patients - i.e. chronological age, age at onset, or duration of diabetes, signs of microangiopathy. Furthermore, in our study a standard meal was given prior to the clearance investigation to enhance the "long-term" effect of different protein intake.

We chose not to supplement with phosphate for the lowering in phosphate intake on an LPD as we wanted to examine the usual situation of a decrease in dietary protein. The quantative reduction of protein content might not be the only contributor to the reduction of GFR. Thus, the lowering in phosphate intake on LPD may also influence renal function, as well as possible differences in amino acid composition of the two diets [23].

Glycaemic control is a well-known modulator of renal function in diabetes [24-26]. The present observations of unchanged levels of blood glucose and serum fructosamine on the various diets suggest that the influence of LPD on renal function occurs independently of glycaemic control. This confirms earlier findings [16].

The present findings of unchanged clearance of renal plasma flow and a tendency of decreased filtration fraction after LPD have been reported earlier in hyperfiltering diabetic patients [16]. In experimental diabetes, a reduction of single nephron GFR following an LPD has also been shown to be accompanied mainly be a decrease in the transcapillary pressure gradient [14]. In healthy subjects though, and in adolescent patients with short-term diabetes (mean 5 years) without signs of renal disease or other late diabetic complications, a parallel decrease in RPF and GFR was seen after LPD $[13,15]$. These divergent results might be explained by the fact that the diabetic patients, as well as the healthy control patients in the latter of these studies, had a normal renal function but were made hyperfiltering by a very high protein diet. One could therefore hypothesise that normal subjects and diabetic patients with an intact renal function might react differently in renal haemodynamics than diabetic patients with more longstanding diabetes and with signs of early functional and/or structural renal changes.

It should be pointed out, however, that data on renal plasma flow and filtration fraction based on $\mathrm{p}$ aminohippuric acid clearance studies should be interpreted with some caution in patients with diabetes. In the present study, as in others [15, 16], there was a wide variation in the clearance of $p$-aminohippuric acid values. A few patients showed a great variability in the clearance of $\mathrm{p}$-aminohippuric acid with very low values that was not seen in the clearance of inulin which could partly be attributed to methodological problem but may also, for unknown reasons, be due to variabilities in tubular function. This might also explain the divergent results concerning renal plasma flow in diabetic patients that have been reported in earlier studies [15, 16, 27].

In order to standardise the investigation of albumin excretion rate and to eliminate the variability due to physical activity, we measured albumin excretion during the clearance investigation. The parallel decline in GFR and urinary albumin excretion on LPD, seen in 
the hyperfiltering group only, is in agreement with the hypothesis that urinary albumin excretion is dependent on intraglomerular haemodynamic factors $[8,9]$ and also consistent with earlier findings [16, 23]. However, as fractional albumin clearance also was reduced in group $\mathrm{H}$, this indicates that a decrease in albumin excretion rate is not only dependent on GFR but alternative explanations are also to be found [16].

Several studies in diabetic humans and in diabetic rats have failed to show an association between protein intake and blood pressure [14, 15, 23]. We have no apparent explanation for the slight decrease in systolic, but not diastolic blood pressure, seen in initially hyperfiltering patients after LPD. As the magnitude of fall in systolic blood pressure was small, it is reasonable to assume that this could only have had a marginal influence on the measured kidney function parameters.

In conclusion, this study has shown that an LPD will reduce GFR in diabetic patients. The effect is more pronounced in hyperfiltering patients and is accompanied by a decrease in albumin excretion rate and systolic blood pressure in these patients. Thus, if glomerular hyperfiltration initiates or accelerates the renal damage in diabetes as suggested by Brenner et al. [4], a moderate protein restriction could be recommended to hyperfiltering diabetic patients in addition to intensive metabolic regulation and early antihypertensive treatment. However, further studies have to ascertain the long-term renal functional effectivness of dietary protein restriction in diabetic patients.

Acknowledgements. This study was supported by grants from the Swedish Diabetes Foundation and Tielman's Fund for Pediatric Research. The food for the project was kindly provided by Findus $A B$, Sweden. We also want to thank dietician U. Nilsson for helping us with designing the diets and M.Agrén, E. Zettergren, and G. M. Taube for technical and laboratory assistance.

\section{References}

1. Mogensen CE, Österby R, Gundersen HJC (1979) Early functional and morfological vascular renal consequences of the diabetic state. Diabetologia 17: 71-76

2. Mogensen CE, Steffes MW, Deckert T, Christiansen JS (1981) Functional and morfological renal manifestations in diabetes mellitus. Diabetologia 21: 89-93

3. Mauer SM, Steffes MW, Brown DM (1981) The kidney in diabetes. Am J Med 70: 603-612

4. Brenner BM, Meyer TW, Hostetter TH (1982) Dietary protein intake and the progressive nature of kidney disease: The role of hemodynamically mediated glomerular injury in the pathogenesis of progressive glomerular sclerosis in aging, renal ablation and intrinsic renal disease. N Engl J Med 307: 652-659

5. Viberti GC, Hill RD, Jarett RJ, Agryopoulos A, Mahmud E, Keen H (1982) Microalbuminuria as a predictor of clinical nephropathy in insulin dependent diabetes. Lancet I: 1430-1432

6. Mathiesen ER, Oxenboll K, Johansen K, Svendsen PA, Deckert $T$ (1984) Incipient nephropathy in Type 1 (insulin-dependent) diabetes. Diabetologia 26: 406-410

7. Mogensen CE, Christansen CK (1984) Predicting diabetic nephropathy in insulin-dependent patients. N Engl J Med 311: $89-393$

8. Brenner BM, Hostetter TH, Humes HD (1978) Molecular basis of proteinuria of glomerular origin. N Engl J Med 298: 826-833
9. Deen WM, Satrat B (1981) Determinants of glomerular filtration of proteins. Am J Physiol 214: F162-F170

10. Viberti GC, Keen H (1981) The patterns of proteinuria in diabetes mellitus. Diabetes 33: 686-692

11. Viberti GC, Wiseman MJ (1986) The kidney in diabetes: significance of the early abnormalities. Clin Endocrinol Metab 15 $753-782$

12. Hostetter TH, Troy JL, Brenner BM (1981) Glomerular hemodynamics in experimental diabetes. Kidney Int 19: 410-415

13. Pullman TN, Alving AS, Dern RJ, Landowne M (1954) The influence of dietary protein intake on specific renal functions in normal man. J Lab Clin Med 44: 320-332

14. Zats R, Meyer TW, Rennke H, Brenner BM (1985) Predominance of hemodynamic rather than metabolic factors in the pathogenesis of diabetic glomerulopathy. Proc Natl Acad Sci USA 82: 5963-5967

15. Kupin WC, Cortes P, Dumler F, Kilates MC, Lewin NW (1987) Effect on renal function of change from high to moderate protein intake in type-1 diabetic patients. Diabetes 36: 73-79

16. Wiseman MJ, Bognetti E, Dodds R, Keen H, Viberti GC (1987) Changes in renal function in response to protein restricted diet in Type 1 (insulin-dependent) diabetic patients. Diabetologia 30: $154-159$

17. Linné T, Körner A, Rudberg S, Persson B (1988) Prostaglandin synthesis inhibition does not normalize GFR or decrease albumin excretion in moderatly hyperfiltrating diabetes mellitus. Abstract. Kidney Int 30: 199

18. Gomori J (1942) Modification of colorimetric phosphorous determination for use with photoelectric colorimeter. J Lab Clin Med 27: 955-960

19. Hilger HH, Klümper SD, Ullrich J (1958) Mikroanaly-tische Untersuchungen über die Wasser- und Natriumrückresorption aus den Sammelrohrenden der Säugetierniere. Pflugers Arch 267: 218-237

20. Smith HW, Finkelstein N, Aliminosa L, Crawford B, Graber M (1945) The renal clearances of substituted hippuric acid and derivatives and other aromatic acids in dog and man. $\mathbf{J}$ Clin Invest $24: 388-401$

21. Baker JR, Metcalf PA, Johnson RN, Newman D, Riezt P (1985) Use of protein-based standards in automated colorimetric determinations of fructosamine in serum. Clin Chem 31: 1550-1554

22. Cohen DL, Dodds RA, Viberti GC (1987) Effect of protein restriction in insulin dependent diabetics at risk of nephropathy. $\mathrm{Br}$ Med J 294: 795-798

23. Dhaene M, Sabot J-P, Yvan P, Doutrelepont J-M, Vanherweghem J-L (1987) Effects of acute protein load of different sources on glomerular filtration rate. Kidney Int 32 [Suppl 22]: S25-S28

24. Wiseman MJ, Saunders AJ, Keen H, Viberti GC (1985) Effect of blood glucose control on increased glomerular filtration rate and kidney size in insulin dependent diabetes. N Engl J Med 312: 617-621

25. Mogensen CE, Andersen MJF (1975) Increased kidney size and glomerular filtration rate in untreated juvenile diabetes: normalization by insulin treatment. Diabetologia 11: 221-224

26. Feldt-Rasmusen B, Mathiesen ER, Deckert $T$ (1986) Effect of two years strict metabolic control on the progression of incipient nephropathy in insulin-dependent diabetes. Lancet II: $1300-1304$

27. Dahlquist G, Aperia A, Broberger O, Persson B, Wilton P (1983) Renal function in relation to metabolic control in children with diabetes of different duration. Acta Paediatr Scand 72: 903-909

Received: 4 July 1988

and in revised form: 11 October 1988

Dr. S. Rudberg

Department of Paediatrics

St.Göran's Children's Hospital

S-112 81 Stockholm

Sweden 